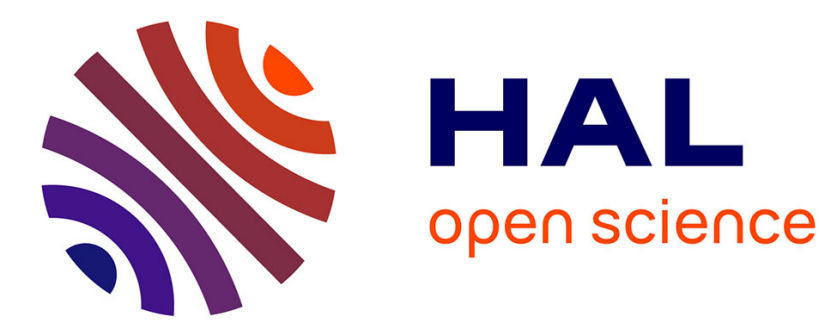

\title{
Surface Patterning Using Two-Phase Laminar Flow and In Situ Formation of Aryldiazonium Salts
}

\author{
Andrew Gross, Volker Nock, Matthew Polson, Maan M Alkaisi, Alison
}

Downard

\section{- To cite this version:}

Andrew Gross, Volker Nock, Matthew Polson, Maan M Alkaisi, Alison Downard. Surface Patterning Using Two-Phase Laminar Flow and In Situ Formation of Aryldiazonium Salts. Angewandte Chemie International Edition, 2013, 52 (39), pp.10261-10264. 10.1002/anie.201305024 • hal-03016224

\section{HAL Id: hal-03016224 \\ https://hal.science/hal-03016224}

Submitted on 20 Nov 2020

HAL is a multi-disciplinary open access archive for the deposit and dissemination of scientific research documents, whether they are published or not. The documents may come from teaching and research institutions in France or abroad, or from public or private research centers.
L'archive ouverte pluridisciplinaire HAL, est destinée au dépôt et à la diffusion de documents scientifiques de niveau recherche, publiés ou non, émanant des établissements d'enseignement et de recherche français ou étrangers, des laboratoires publics ou privés. 


\title{
Surface Patterning using.Two-Phase Laminar Flow and In-Situ Formation of Aryldiazonium Salts**
}

\author{
Andrew. J. Gross, Volker Nock, Matthew. I. J. Polson, Maan. M. Alkaisi, and Alison. J. Downard*
}

Patterned nanoscale molecular films will be a key component of advanced devices such as novel chemical and biological sensors and nanoelectronic systems. For long-established surface modification strategies such as self-assembled monolayers of alkanethiols at noble metal surfaces, and reactions of silanes at oxide surfaces, patterning strategies have reached a high level of sophistication. ${ }^{[1]}$ In contrast surface patterning using aryldiazonium salts is relatively undeveloped. ${ }^{[2]}$

Modification of substrates using aryldiazonium ions proceeds through reductive generation of an aryl radical that attacks the surface to form a covalent bond. ${ }^{[3]}$ The reaction proceeds at a wide range of metallic, semiconductor and insulator materials. ${ }^{[4]}$ For substrates such as carbon and silicon, the resulting film is anchored very strongly to the surface, thus leading to the enticing possibility of preparing practical and robust materials for a range of applications. Reduction of the aryldiazonium ion can be carried out electrochemically, by addition of a chemical reducing agent, or in some cases, by the substrate itself at open-circuit potential ('spontaneous' grafting). ${ }^{[4]}$ Electrografting and spontaneous grafting give interesting possibilities for patterning using aryldiazonium modifiers. For example, an array of protein spots can be patterned onto a gold substrate by pin electrospotting. ${ }^{[5]}$ For this patterning method, the solution of diazoniumderivatized protein and the counter electrode are confined within a fine pipette tip. A reducing potential is then applied at the substrate (working electrode) to graft protein from individual spots of solution. In contrast, microcontact printing with aryldiazonium salt inks exploits the spontaneous grafting reaction for surface patterning. This strategy has been used to pattern carbon, silicon and copper substrates with films of 1-4 nm thickness and feature sizes down to $10 \mu \mathrm{m}^{[6]}$ However, the spontaneous reaction makes some other patterning techniques impossible to implement. For example, under conditions in which spontaneous reactions can proceed, the scanning electrochemical microscope (SECM) cannot be used in a straightforward manner to selectively 'write' patterns of films from

[*] Dr A. J. Gross, Dr M. I. J. Polson, Prof. A. J. Downard MacDiarmid Institute for Advanced Materials and Nanotechnology, Department of Chemistry, University of Canterbury, Christchurch 8140, New Zealand Fax: (+64) 3-3642110

E-mail: alison.downard@canterbury.ac.nz

Dr V. Nock, Assoc. Prof. M. M. Alkaisi

MacDiarmid Institute for Advanced Materials and Nanotechnology, Department of Electrical and Computer Engineering, University of Canterbury, Christchurch 8140, New Zealand

[**] This work was supported by the MacDiarmid Institute for Advanced Materials and Nanotechnology and the University of Canterbury

Supporting information for this article is available on the WWW under http://www.angewandte.org or from the author.

solutions of aryldiazonium salts because the whole surface exposed to the solution will be modified. ${ }^{[7]}$

Several ingenious patterning strategies have been reported in which the SECM is used to generate aryldiazonium ions only in the vicinity of the tip electrode. ${ }^{[8]}$ Most relevant to the present work is the method of Pedersen, Daasbjerg and co-workers ${ }^{[8 b]}$, which is based on Tour and co-workers' earlier demonstration that a film can be grafted after in-situ formation of an aryldiazonium ion by reaction of the corresponding triazene with $\operatorname{acid}^{[9]}$ (Scheme 1a). By electrogenerating the acid at the tip electrode of the SECM in a solution of the aryltriazene, while maintaining a negative potential on the glassy carbon (GC) substrate, Pedersen, Daasbjerg and coworkers electrografted small rings of film (tens of microns in size) in the area beneath the tip. There was no evidence that the triazene underwent spontaneous grafting over other areas of the surface. ${ }^{[8 b]}$

(a)<smiles>[R]c1ccc(/N=N/N(C)C)cc1[I-]</smiles>

(b)

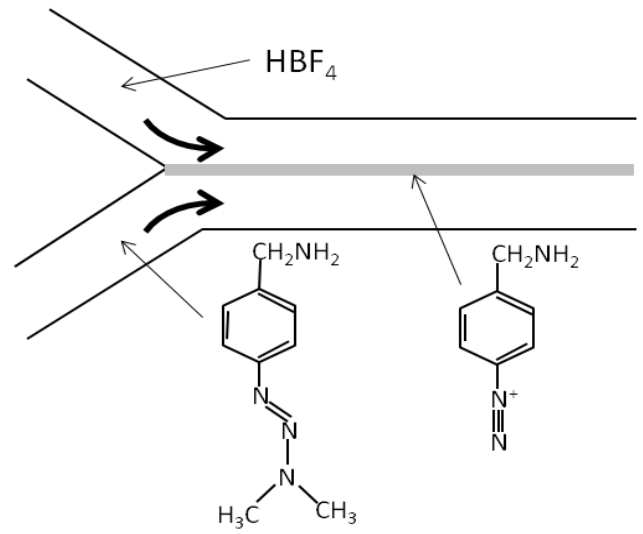

Scheme 1. (a) Reaction of aryltriazene with acid to give the corresponding diazonium ion that grafts to a surface; (b) strategy for in-situ formation of aminomethylbenzenediazonium ion at the interface of streams of $\mathrm{HBF}_{4}$ and [p-(dimethyltriaz-1-en-1$\mathrm{yl})$ phenyl]methylamine $\left(\mathrm{AMP}_{\mathrm{T}}\right)$. represents the interfacial mixing zone where diazonium ion is generated

Multistream laminar flow is an alternative way to achieve spatially-controlled mixing of reagents. ${ }^{[10]}$ Under conditions of laminar flow, mixing at the interface between two miscible liquids flowing in parallel through a channel occurs by diffusion transverse to the direction of flow. When mixing generates a surface-active species, the surface is modified only in the interfacial mixing region, giving a pattern with a lateral feature size significantly smaller than 
the flowing streams. ${ }^{[10-11]}$ Whitesides and co-workers demonstrated this technique by patterning narrow 'lines' (less than $5 \mu \mathrm{m}$ width) of metals, polymers and inorganic crystals onto various substrates from solutions flowing in microchannels of $\sim 100$ or $200 \mu \mathrm{m}$ width. ${ }^{[10]}$

Herein we apply two-phase laminar flow to form an aryldiazonium ion at the interface between the two streams, one containing an aryltriazene and the other an acid (Scheme 1b). Aryldiazonium ion is generated in a narrow line in the center of the microfluidic channel and grafts spontaneously to the carbon substrate.

Preliminary experiments (see Supplementary Information) investigated in-situ diazonium ion formation, the grafting reaction, and characterization of the films. Films were electrografted to GC electrodes and to a planar and smooth GC-like substrate (pyrolyzed photoresist film, PPF ${ }^{[12]}$ ) using solutions of $2 \mathrm{mM}$ [p-(dimethyltriaz1-en-1-yl)phenyl]methylamine $\left(\mathrm{AMP}_{\mathrm{T}}\right)$ in $0.1 \mathrm{M} \mathrm{HBF}_{4}$. The grafted films were characterized by electrochemistry and atomic force microscopy (AFM) (Supplementary Information). These experiments confirmed, as expected, that the corresponding diazonium ion was formed in-situ from the reaction of $\mathrm{AMP}_{\mathrm{T}}$ with $\mathrm{HBF}_{4}$, and that an AMP film was grafted to the substrate surface.

The feasibility of grafting under flow conditions was established by single-stream patterning. A microfluidic patterning device was fabricated in poly(dimethylsiloxane) (PDMS) by replica molding ${ }^{[13]}$ (Figure S2) and sealed to the PPF surface. Using a syringe pump, a freshly prepared solution of $2 \mathrm{mM} \mathrm{AMP}_{\mathrm{T}}$ in $0.1 \mathrm{M} \mathrm{HBF}_{4}$ was flowed as a single stream through an $\sim 100 \mu \mathrm{m}$ width channel in the PDMS mold. After $30 \mathrm{~min}$ flow at $0.5 \mathrm{~mL} \mathrm{~min}^{-1}$ the mold was peeled off the PPF substrate while flushing the surface with water, thus minimizing contact of the grafting solution (and unwanted spontaneous grafting) with areas of the surface outside the microchannel. Figure 1 shows scanning electron microscopy (SEM) images of the modified surface (Figure 1a) and of the control surface (Figure 1b). The control was treated in the same way as the sample but using a $2 \mathrm{mM}$ solution of $\mathrm{AMP}_{\mathrm{T}}$ only (no added acid). The images clearly show that in the presence of $\mathrm{HBF}_{4}$ a film is grafted to the surface, while in the absence of acid, only traces of PDMS residues remain on the surface. This result confirms first, that aryldiazonium ion is generated in the presence of acid, and second, that a film is spontaneously grafted to PPF under the flow conditions.
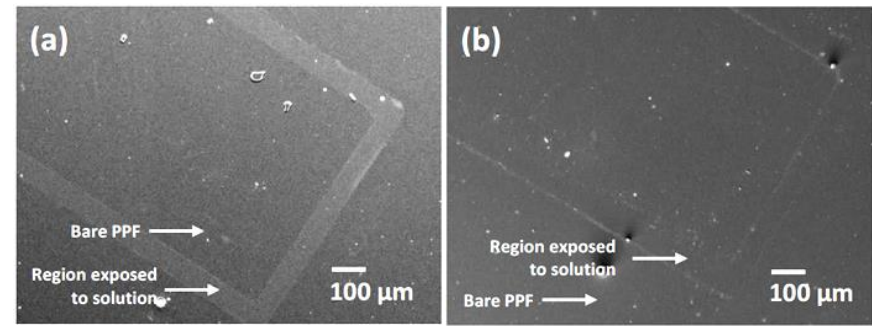

Figure 1. SEM micrographs of (a) AMP film grafted to a PPF surface from a flowing solution prepared from $2 \mathrm{mM} \mathrm{AMP}_{\mathrm{T}}$ and $0.1 \mathrm{M} \mathrm{HBF}_{4}$; (b) blank for experiment described in (a)

The thickness and uniformity of the spontaneously grafted film were examined by depth-profiling using the atomic force microscope. ${ }^{[12 a]}$ Small sections of film from the single flow channel near the flow inlet and outlet (Figure 2a, note: one inlet was blocked during single-stream flow) were removed by scratching with the AFM tip (Figure 2b) and profiled (Figure 2c). The average film thicknesses at the inlet and outlet were $2.5 \pm 0.2 \mathrm{~nm}$ and $2.3 \pm 0.2 \mathrm{~nm}$, respectively. Clearly, there is no significant difference in thickness between the two regions separated by $\sim 10 \mathrm{~mm}$, indicating excellent film uniformity on the macroscale. The thickness of the film is consistent with a multilayer structure, as is commonly found when grafting from aryldiazonium salt solutions. ${ }^{[14]}$

(a)

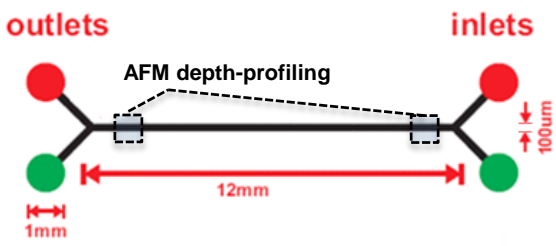

(b)

(c)
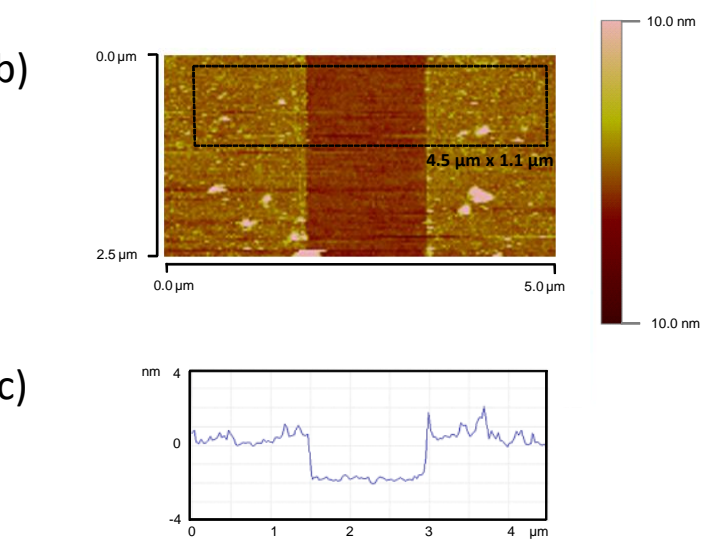

Figure 2. (a) Layout of microfluidic device indicating regions film thickness was measured; (b) tapping mode AFM image of AMP film near the channel inlet, with a section of film removed; (c) average line profile across the film in (b).

Applying the system described above to two-phase laminar flow patterning involved introducing separate solutions of $2 \mathrm{mM}$ $\mathrm{AMP}_{\mathrm{T}}$ in $0.1 \mathrm{M} \mathrm{KCl}$, and $0.2 \mathrm{M} \mathrm{HBF}_{4}$, into the two inlets of a microfluidic channel in a PDMS mold sealed onto a piece of PPF. The two solutions were introduced within a few seconds of each other via controlled infusion using a dual syringe pump. Patterning was examined at two flow rates and flow times. At the end of the flow time, the PDMS mold was immediately removed from the substrate, with simultaneous rinsing of the surface.

Figure 3a shows an optical micrograph of a line of AMP grafted to PPF using two-phase patterning with flow rate $=0.2 \mathrm{~mL} \mathrm{~min}^{-1}$ and flow time $=60 \mathrm{~min}$. It is clear that the line of grafted film is significantly narrower than the microchannel and its position is consistent with grafting occurring only near the interface between the two flowing streams. The line width is approximately $15 \mu \mathrm{m}$ near the inlets and broadens progressively down the channel; this is expected as the effects of diffusion become more pronounced as the contact time between the two solutions increases. AFM images were obtained of the film $\sim 100 \mu \mathrm{m}$ downstream of the $\mathrm{Y}$-junction, and reveal (Figures $3 b$ and c) that the grafted film is very rough with protrusions ranging in height from $\sim 5-250 \mathrm{~nm}$. Even after extended (30 min) sonication in $\mathrm{N}, \mathrm{N}$-dimethylformamide, there was no significant change in the film morphology or apparent surface coverage, indicating that the film material is strongly attached to the substrate.

In a second set of experiments, the solution flow rate was increased to $2 \mathrm{~mL} \mathrm{~min}^{-1}$ and the flow time decreased to $\sim 1 \mathrm{~min}$. The images in Figure 4 show the details of a film grafted under these conditions. SEM analysis revealed the formation of a well-defined line of film close to the center of the channel (Figure 4a). The topographical AFM image (Figure $4 \mathrm{~b}$ ) and average line profile (Figure $4 \mathrm{c}$ ) reveal a line width of $\sim 900 \mathrm{~nm}$ and an average height 
(over a $1.2 \times 1.8 \mu \mathrm{m}^{2}$ area) of $2.4 \mathrm{~nm}$. The smaller line width and decreased height of these films compared with film grafted at slower flow rate and longer flow times (Figure 3) are qualitatively as expected. ${ }^{[11]}$ Under conditions of laminar flow, the width of the diffusive mixing zone at the interface of two streams decreases as the flow rate increases, accounting for the narrower grafted line at higher flow rate. Decreasing the flow time simply reduces the grafting time and hence yields a thinner film, as found for films grafted spontaneously from bulk solution. However, the flow rate will also have a difficult-to-predict effect on film thickness: as flow rate increases, the aryldiazonium ion solution is replenished more completely at the surface, promoting faster film growth, but above a certain flow rate, aryl radicals will be swept away from the surface before being able to react with the surface, thus slowing film growth.

(a)

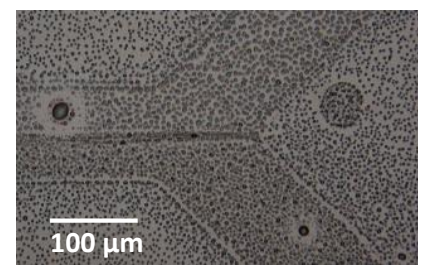

(b)

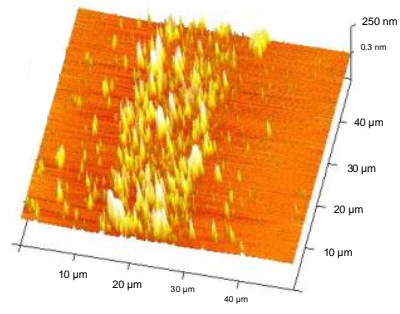

(c)

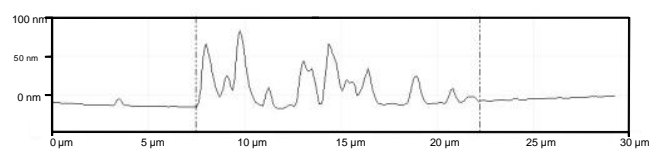

Figure 3. Two-phase laminar flow patterned AMP film prepared with flow rate $=0.2 \mathrm{~mL} \mathrm{~min}^{-1}$ and flow time $=60 \mathrm{~min}$. (a) Optical micrograph of water condensation figure; (b) 3-D AFM image; (c) single line profile.
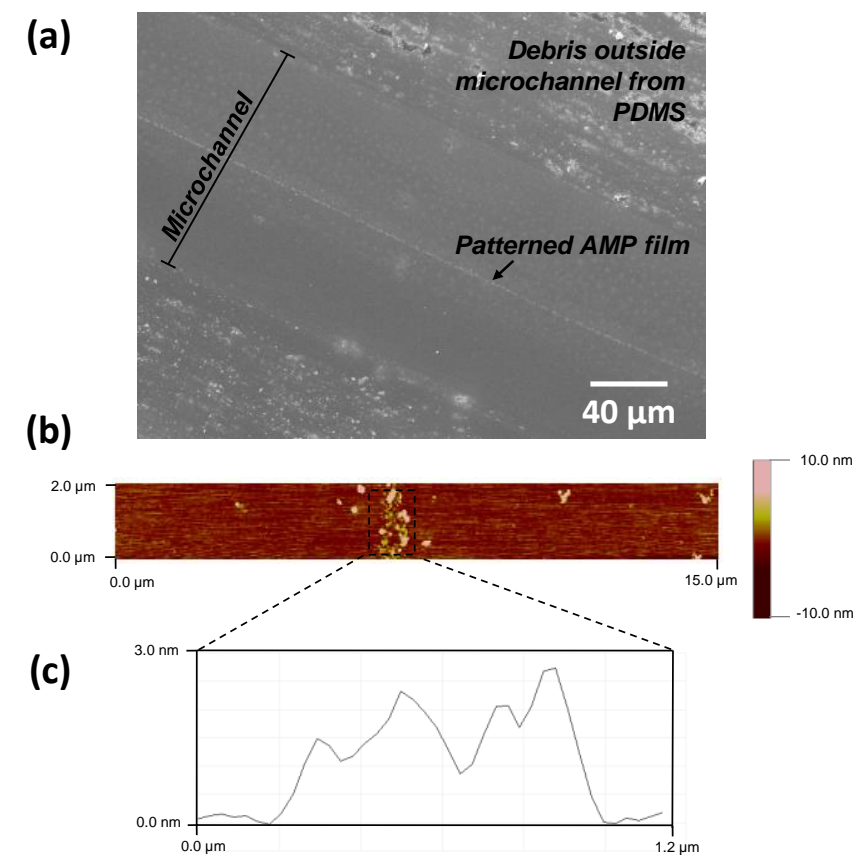

Figure 4. Two-phase laminar flow patterned AMP film prepared with flow rate $=2 \mathrm{~mL} \mathrm{~min}^{-1}$ and flow time $=1 \mathrm{~min}$. (a) SEM image; (b) 2-D AFM image; (c) average line profile of a $1.2 \times 1.8 \mu \mathrm{m}$ region.
In summary, we have successfully demonstrated use of twophase laminar flow in microfluidic channels to pattern low micro- and nanoscale organic films onto a GC-like substrate. The method has the usual advantages inherent in grafting from aryldiazonium ion solutions: very stable attachment of the patterned film, versatility in terms of aryl groups that can be grafted, and compatibility with a wide range of substrates. ${ }^{[4]}$ In addition, the patterning method is very rapid and does not require sophisticated equipment. Because grafting only occurs at the interface of the flowing streams, lines with sub-micron width can be grafted without the technical difficulties associated with fabricating and using sub- micron channels. Future work will focus on optimizing experimental conditions to improve film uniformity and will explore the full power of microfluidics for creating patterns with a wide range of shapes and layouts. Use of patterned aminomethylphenyl films as tether layers for immobilisaton of target species will also be investigated. Amine-terminated tethers offer the opportunity for facile coupling reactions, in particular with biomolecules relevant to biosensor fabrication.

\section{Experimental Section}

Prior to mixing with $\mathrm{HBF}_{4}$ or introducing into the flow system, solutions of $\mathrm{AMP}_{\mathrm{T}}$ were sonicated for $5 \mathrm{~min}$ at $40{ }^{\circ} \mathrm{C}$ to aid dissolution. All flow experiments were undertaken after cooling solutions to room temperature $\left(\sim 22{ }^{\circ} \mathrm{C}\right)$. At the completion of a flow experiment, the PDMS mold was removed from the PPF substrate with simultaneous flushing with water. Grafted surfaces were rinsed with water followed by acetonitrile, sonicated for $60 \mathrm{~s}$ in acetonitrile, rinsed with isopropanol, and dried under a stream of nitrogen gas.

Received: ((will be filled in by the editorial staff))

Published online on ((will be filled in by the editorial staff))

Keywords: aryltriazene $\cdot$ grafting $\cdot$ diazo compounds $\cdot$ radical reactions $\cdot$ surface chemistry $\cdot$ microfluidic channels

[1] M. Geissler, Y. Xia, Adv. Mater. 2004, 16, 1249-1269.

[2] A. J. Downard, A. J. Gross, B. M. Simons, in Aryl Diazonium Salts: New Coupling Agents in Polymer and Surface Science (Ed.: M. M. Chehimi), Wiley-VCH, Weinheim, 2012, pp. 53-70.

[3] a) M. Delamar, R. Hitmi, J. Pinson, J.-M. Savéant, J. Am. Chem. Soc. 1992, 114, 5883-5884; b) P. Allongue, M. Delamar, B. Desbat, O.

Fagebaume, R. Hitmi, J. Pinson, J.-M. Savéant, J. Am. Chem. Soc. 1997, 119, 201-207.

[4] a) D. Bélanger, J. Pinson, Chem. Soc. Rev. 2011, 40, 3995-4048; b) J. Pinson, F. Podvorica, Chem. Soc. Rev. 2005, 34, 429-439.

[5] B. P. Corgier, S. Bellon, M. Anger-Leroy, L. J. Blum, C. A. Marquette, Langmuir 2009, 25, 9619-9623.

[6] a) D. J. Garrett, J. Lehr, G. M. Miskelly, A. J. Downard, J. Am. Chem. Soc. 2007, 129, 15456-15457; b) J. Lehr, D. J. Garrett, M. G. Paulik, B. S

Flavel, P. A. Brooksby, B. E. Williamson, A. J. Downard, Anal. Chem. 2010, 82, 7027-7034.

[7] a) A. Adenier, E. Cabet-Deliry, A. Chausse, S. Griveau, F. Mercier, J. Pinson, C. Vautrin-Ul, Chem. Mater. 2005, 17, 491-501; b) I. Gallardo, J.

Pinson, N. Vila, J. Phys. Chem. B 2006, 110, 19521-19529.

[8] a) C. Cougnon, F. Gohier, D. Bélanger, J. Mauzeroll, Angew. Chem. Int. Ed. 2009, 48, 4006-4008; b) M. Kongsfelt, J. Vinther, K. Malmos, M. Ceccato, K. Torbensen, C. S. Knudsen, K. V. Gothelf, S. U. Pedersen, K. Daasbjerg, J. Am. Chem. Soc. 2011, 133, 3788-3791.

[9] J. L. Hudson, H. Jian, A. D. Leonard, J. J. Stephenson, J. M. Tour, Chem. Mater. 2006, 18, 2766-2770.

[10] P. J. A. Kenis, R. F. Ismagilov, G. M. Whitesides, Science 1999, 285, 83-85.

[11] P. J. A. Kenis, R. F. Ismagilov, S. Takayama, G. M. Whitesides, S. L. Li, H. S. White, Acc. Chem. Res. 2000, 33, 841-847.

[12] a) P. A. Brooksby, A. J. Downard, Langmuir 2004, 20, 5038-5045; b) S. Ranganathan, R. L. McCreery, Anal. Chem. 2001, 73, 893-900. 
[13] D. C. Duffy, J. C. McDonald, O. J. A. Schueller, G. M. Whitesides, Anal. Chem. 1998, 70, 4974-4984.

[14] F. Barrière, A. J. Downard, J. Solid State Electrochem. 2007, 12,

$1231-1244$. 


\section{Surface patterning}

Andrew. J. Gross, Volker Nock,

Matthew. I. J. Polson, Maan M. Alkaisi, and Alison. J. Downard* Page - Page

Surface Patterning using Two-Phase Laminar Flow and In-Situ Formation of Aryldiazonium Salts

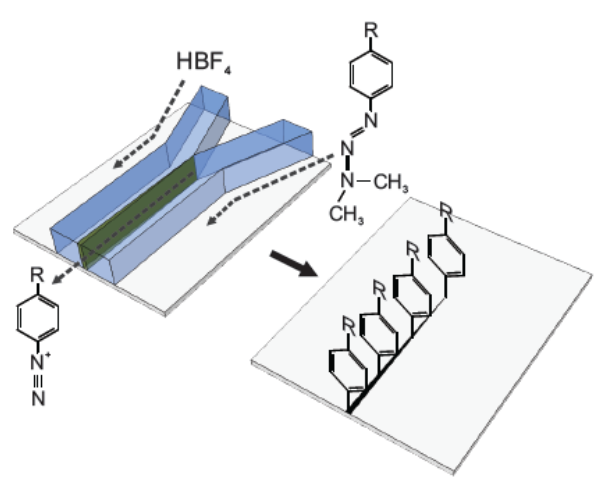

In the reaction zone: Reaction of an aryltriazene with acid generates the corresponding aryldiazonium ion. When this reaction takes place in the mixing zone, at the interface between two streams flowing laminarly and in parallel through a $100 \mu \mathrm{m}$ microchannel, a submicrometer line of organic film is grafted at the substrate surface. 


\section{Supplementary Information}

\section{Surface Patterning using Two-Phase Laminar Flow and In-Situ Formation of Diazonium Salts**}

Andrew. J. Gross, Volker Nock, Matthew. I. J. Polson, Maan M. Alkaisi, and A. J. Downard*

\section{Solvents and Reagents}

All aqueous solutions were prepared using Milli-Q water (Millipore, USA) with resistivity $\geq 18 \mathrm{M} \Omega / \mathrm{cm}$. $N, N$-dimethylformamide (Scharlau Chemie, 99.9\%), dichloromethane (DCM, Acros Organics, 99.5\%), isopropyl alcohol (IPA, Sigma Aldrich), ethyl acetate (EtOAc, Emsure ${ }^{\circledR}$ ACS, ISO, Reag), methanol (MeOH, Sigma Aldrich, $\geq 99.8 \%$ ), potassium chloride (KCl, J. T. Baker, 100\%), p-(aminomethyl)aniline (99.0\%), fluoroboric acid ( $\mathrm{HBF}_{4}, 50$ wt. \% in water, Acros Organics), benzyl chloroformate $(\mathrm{CBzCl}$, Acros Organics, 97 wt. \% stabilised) and glacial acetic acid (May \& Baker, 99.7\%) were used as received. Tetrabutylammonium tetrafluoroborate $\left(\mathrm{TBABF}_{4}\right)$ was prepared and isolated by neutralisation of TBAOH (40 wt. \% in water, Acros Organics) with $\mathrm{HBF}_{4}$.

Acetonitrile (ACN, 99.9\%, BDH) and tetrahydrofuran (THF, Sigma Aldrich, 99.9\%) were refluxed under $\mathrm{N}_{2}$ for at least $2 \mathrm{~h}$ prior to distilling in a $\mathrm{N}_{2}$ atmosphere.

\section{Synthesis of [p-(dimethyltriaz-1-en-1-yl)phenyl]methylamine (AMPT)}

[p-(Dimethyltriaz-1-en-1-yl)phenyl]methylamine $\left(\mathrm{AMP}_{\mathrm{T}}\right)$ was prepared using the general method of Hansen and co-workers. ${ }^{[15]}$ The synthesis route is shown in Figure S1.

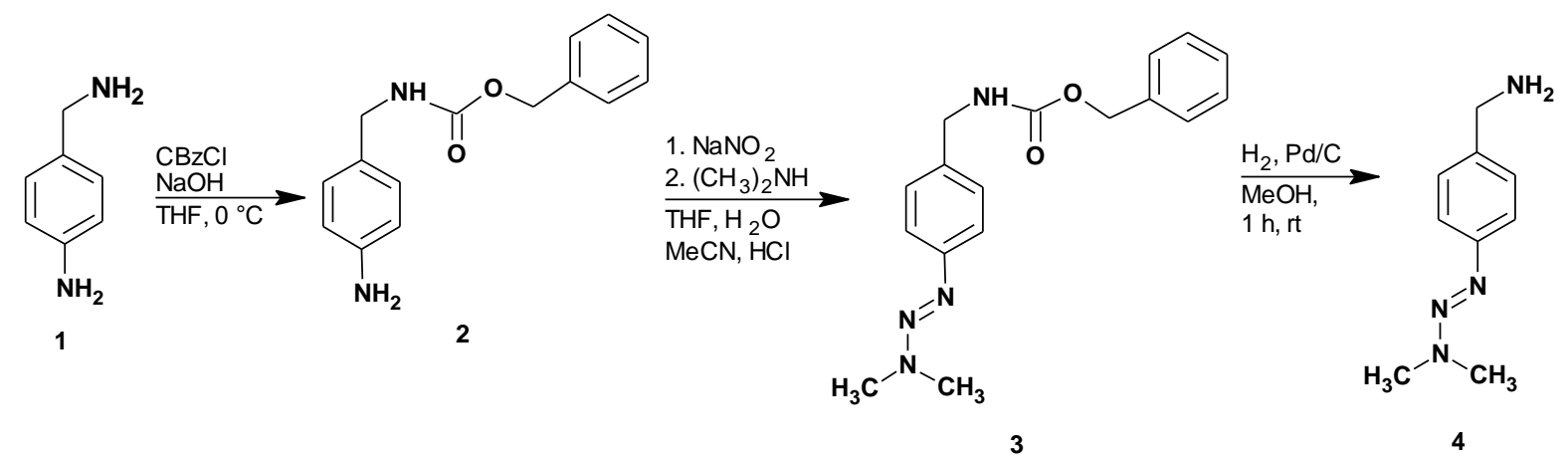

Figure S1. Scheme for synthesis of AMPт. 
p-(Aminomethyl)aniline 1 (1.00 g, $8.22 \mathrm{mmol}$ ) was dissolved in THF (30 mL) and NaOH (1 M, 7.3 mL). The mixture was stirred and then cooled in an ice/acetone bath. Benzyl chloroformate (1.29 mL, 9.20 $\mathrm{mmol})$ in THF $(10 \mathrm{~mL})$ was then added dropwise over a period of $10 \mathrm{~min}$ at $0{ }^{\circ} \mathrm{C}$. The reaction mixture was stirred for $17.5 \mathrm{~h}$ at room temperature. The aqueous phase was extracted with EtOAc $(3 \times 15 \mathrm{~mL})$, and the organics were combined and washed with brine. The solvent was evaporated and the residue was purified by column chromatography (silica gel, DCM/EtOAc 2:1) to afford benzyl (4aminobenzyl)carbamate 2 as a yellow powder $(1.22 \mathrm{~g}, 4.76 \mathrm{mmol}, 58 \%)$, m.p. $63-65^{\circ} \mathrm{C} ; \delta_{\mathrm{H}}(500 \mathrm{MHz}$, $\left.\mathrm{CDCl}_{3}, \mathrm{ppm}\right) 4.15\left(2 \mathrm{H}, \mathrm{s}, \mathrm{Ar}-\mathrm{CH}_{2}-\mathrm{N}\right), 5.08\left(2 \mathrm{H}, \mathrm{s}, \mathrm{Ar}-\mathrm{CH}_{2}-\mathrm{O}\right), 6.67\left(2 \mathrm{H}, \mathrm{d},{ }^{3} \mathrm{~J} 8.5 \mathrm{~Hz}, \mathrm{Ar}-\mathrm{H}\right), 7.02(2 \mathrm{H}$, d, $\left.{ }^{3} J 8.5 \mathrm{~Hz}, 2 \times \mathrm{Ar}-\mathrm{H}\right), 7.28-7.34(5 \mathrm{H}, \mathrm{m}, 5 \times \mathrm{Ar}-\mathrm{H})$; HRMS (ESI-TOF) Calcd. for $\mathrm{C}_{15} \mathrm{H}_{16} \mathrm{~N}_{2} \mathrm{O}_{2} \mathrm{Na}^{+}$ 279.1104. Found 279.1101 $\left(\mathrm{MNa}^{+}\right)$.

Compound $2(1.00 \mathrm{~g}, 3.91 \mathrm{mmol})$ was dissolved in a mixture of THF $(8.5 \mathrm{~mL}), \mathrm{H}_{2} \mathrm{O}(8 \mathrm{~mL}), \mathrm{ACN}(4.25$ $\mathrm{mL})$ and concentrated $\mathrm{HCl}(2 \mathrm{~mL})$. The reaction mixture was cooled to $0{ }^{\circ} \mathrm{C}$. A solution of sodium nitrite (350 mg, $5.09 \mathrm{mmol}$ ) dissolved in THF (1.25 mL) and $\mathrm{H}_{2} \mathrm{O}(1.25 \mathrm{~mL})$ was added slowly. Afterwards, the reaction mixture was added dropwise to $40 \%$ dimethylamine $(11 \mathrm{~mL})$ under vigorous stirring, then immediately extracted with DCM $(3 \times 8 \mathrm{~mL})$. The organics were combined and washed with $\mathrm{H}_{2} \mathrm{O}$ before being dried over $\mathrm{Na}_{2} \mathrm{SO}_{4}$, filtered, and concentrated to afford benzyl [4-((1E)-3,3-dimethyl-1-triazen-1yl)benzyl]carbamate 3 as a pale yellow powder (910.6 mg, $2.92 \mathrm{mmol}, 75 \%)$, m.p. $117-119{ }^{\circ} \mathrm{C}, \delta_{\mathrm{H}}(500$ $\left.\mathrm{MHz}, \mathrm{CDCl}_{3}, \mathrm{ppm}\right) 3.31\left(6 \mathrm{H}\right.$, br. s, $\left.2 \times \mathrm{N}_{-} \mathrm{CH}_{3}\right), 4.33\left(2 \mathrm{H}, \mathrm{s}, \mathrm{Ar}-\mathrm{CH}_{2}-\mathrm{N}\right), 5.11\left(2 \mathrm{H}, \mathrm{s}, \mathrm{Ar}-\mathrm{CH}_{2}-\mathrm{O}\right), 7.20-$ $7.23(2 \mathrm{H}, \mathrm{m}, 2 \times \mathrm{Ar}-\mathrm{H}), 7.29-7.36(7 \mathrm{H}, \mathrm{m}, 7 \times \mathrm{Ar}-\mathrm{H})$; HRMS (ESI-TOF) Calcd. for $\mathrm{C}_{17} \mathrm{H}_{20} \mathrm{~N}_{4} \mathrm{O}_{2} \mathrm{Na}^{+}$ 335.1478. Found $335.1480\left(\mathrm{MNa}^{+}\right)$.

Compound 3 (800 mg, $2.56 \mathrm{mmol}$ ) was suspended in $\mathrm{MeOH}(10 \mathrm{~mL})$ and 10\% $\mathrm{Pd} / \mathrm{C}(100 \mathrm{mg})$ was added. The reaction was stirred for $1 \mathrm{~h}$ at room temperature under a $\mathrm{H}_{2}$ atmosphere. The solution was then filtered through Celite and the remaining catalyst washed with $\mathrm{MeOH}$. The solution was evaporated under reduced pressure to afford [p-(dimethyltriaz-1-en-1-yl)phenyl]methylamine $\mathbf{4}$ as a yellow solid (446.15

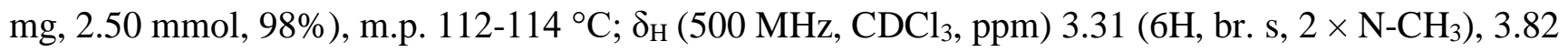
$\left(2 \mathrm{H}, \mathrm{s}, \mathrm{Ar}-\mathrm{CH}_{2}-\mathrm{N}\right), 7.24\left(2 \mathrm{H}, \mathrm{d},{ }^{3} J 8.5 \mathrm{~Hz}, 2 \times \mathrm{Ar}-\mathrm{H}\right), 7.37\left(2 \mathrm{H}, \mathrm{d},{ }^{3} J 8.5 \mathrm{~Hz}, 2 \times \mathrm{Ar}-\mathrm{H}\right)$; HRMS (ESITOF) Calcd. for $\mathrm{C}_{9} \mathrm{H}_{14} \mathrm{~N}_{4} \mathrm{Na}^{+}$201.2240. Found 201.2241 $\left(\mathrm{MNa}^{+}\right)$.

\section{Carbon surface preparation}

Glassy carbon (GC) rod electrodes $(\varnothing=3 \mathrm{~mm}$ ) (Tokai Carbon Co. Ltd) were used for preliminary grafting experiments. GC electrodes were polished successively using $1 \mu \mathrm{m}$ then $0.05 \mu \mathrm{m}$ alumina, sonicated in Milli-Q water for $5 \mathrm{~min}$, and dried under a stream of $\mathrm{N}_{2}$. Pyrolyzed photoresist film (PPF) 
samples $\left(23 \times 23 \mathrm{~mm}^{2}\right)$ were prepared as described previously. ${ }^{[12 \mathrm{a}]}$ Prior to use, all carbon surfaces were rinsed for $10 \mathrm{~s}$ in IPA then dried with a stream of $\mathrm{N}_{2}$.

\section{Microscopy}

Scanning electron microscopy (SEM) micrographs were recorded in secondary electron imaging mode using an 7000 SEM (JEOL) operating with accelerating voltages between 10-15 keV.

Atomic force microscopy (AFM) measurements were recorded in air on dry substrates using a Nanoscope Dimension 3100 and Nanoscope IIIa controller (both Digital Instruments). Topographical imaging was performed in tapping-mode using a silicon cantilever with a fundamental frequency of $200-400 \mathrm{kHz}$ (TAP300Al-G series, Budget Sensors, Innovative Solutions Bulgaria Ltd). Images were recorded at a scan rate of either $1 \mathrm{~Hz}$ or $0.5 \mathrm{~Hz}$ with a resolution of 512 samples per line. The amplitude set point and gains were optimised for each sample. Image processing, thickness and roughness measurements were performed using Nanoscope Analysis v1.2 software.

AFM film thickness measurements by depth profiling followed the procedures reported by Brooksby and co-workers. ${ }^{[12 \mathrm{a}]}$ The method involves mechanically removing a section of the grafted film by 'scratching' with an AFM and then subsequently recording a depth profile across the scratch using a clean AFM tip. The same procedure was applied to regions of unmodified PPF and, in some cases, a shallow scratch of $\leq$ $0.2 \mathrm{~nm}$ was observed. In those cases the measured depths of the films were corrected by the same amount. The depth of each scratch was calculated from topographical height images using the Nanoscope Analysis step height calculation tool. Two scratches were made on each modified area and at least one image was obtained per scratch. Three sections from each image were analysed, giving two measurements per section: one from the left scratch-film boundary and one from the right. Between 12 and 18 film thickness measurements were recorded per sample in order to determine the final average film thickness.

The film thickness of the AMP line pattern prepared at fast flow was determined from an average crosssectional profile $\left(\right.$ area $\left.=1.2 \times 1.8 \mu \mathrm{m}^{2}\right)$.

\section{Microfluidic device fabrication and surface patterning}

The procedure for preparation of the microfluidic patterning device, and subsequent grafting of a patterned molecular film at PPF, is shown in Figure S2. The microchannel molds were fabricated using standard photolithography and replica moulding in poly(dimethylsiloxane) (PDMS, Sylgard® 184, Dow Corning). ${ }^{[13]}$ The SU-8 master was treated with trimethylchlorosilane prior to casting the degassed polymer mix (weight ratio of 10:1, base:curing agent). The PDMS was cured at $80^{\circ} \mathrm{C}$ for $3 \mathrm{~h}$ on a 
hotplate and then cut into $\sim 23 \times 23 \times 7 \mathrm{~mm}^{3}$ slabs. Prior to use, microchannels were cored to give inlet and outlet holes using a biopsy punch. Patterned films were prepared by positioning and clamping the PDMS microchannel mold onto a PPF substrate and introducing solution streams into the microchannels by controlled flow using a Sage M362 syringe pump (Thermo Orion) with either one or two $5 \mathrm{~mL}$ syringes attached. Microchannel dimensions were approximately: width: $100 \mu \mathrm{m}$; height: $50 \mu \mathrm{m}$; length $12 \mathrm{~mm}$.

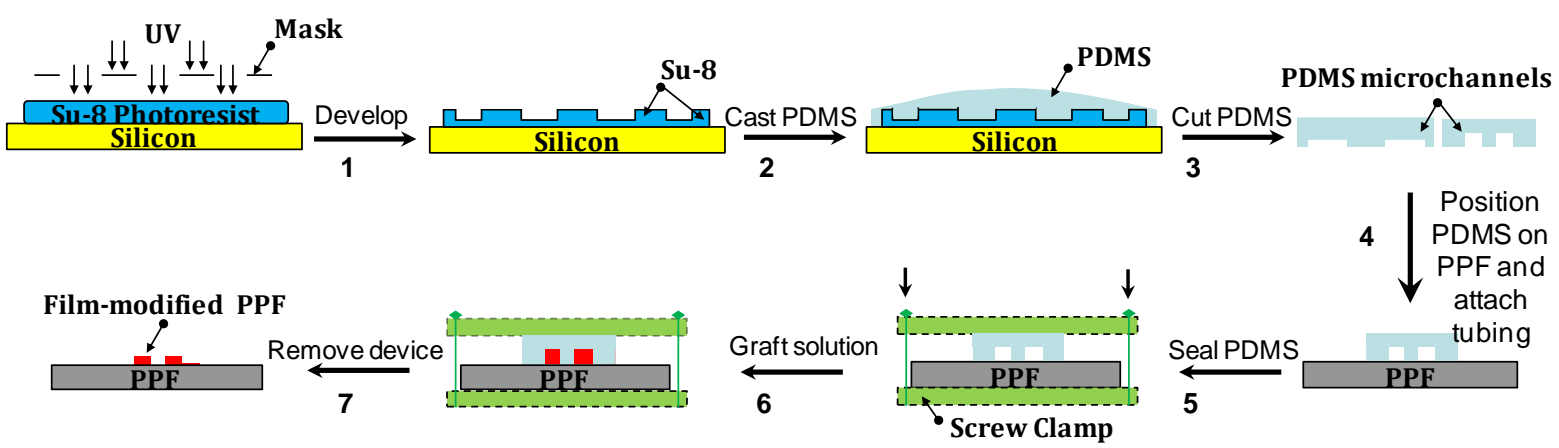

Figure S2. Scheme for the preparation of microchannel molds and the procedure for surface patterning.

\section{Electrografting of aminomethylphenyl (AMP) films at GC and PPF}

Prior to grafting under laminar flow conditions, grafting experiments were undertaken in static solution in a conventional 3-electrode cell. GC and PPF surfaces were modified by electrografting from aqueous solutions of $2 \mathrm{mM} \mathrm{AMP}_{\mathrm{T}}$ and $0.1 \mathrm{M} \mathrm{HBF}_{4}$. The conventional 3-electrode cell ${ }^{[12 \mathrm{a}]}$ comprised GC or PPF as the working electrode, a Pt wire auxiliary electrode and a saturated calomel electrode (SCE) as reference. Figure S3 shows 5 repeat cyclic voltammograms (CVs) obtained at PPF at scan rate $=100 \mathrm{mV} \mathrm{s}^{-1}$. The peak is assigned to reduction of aminomethyldiazonium ion that has been formed in solution and the decrease in peak current on repeat scans is typical of aqueous grafting behaviour of other aryldiazonium ions. $^{[16]}$

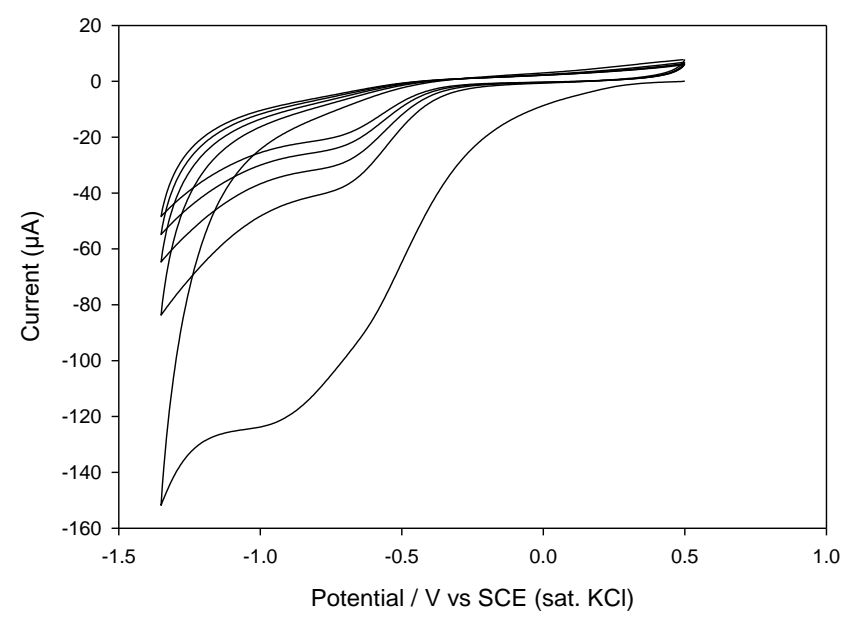


Figure S3. Five consecutive scans obtained at a PPF electrode (scan rate $=100 \mathrm{mV} \mathrm{s}^{-1}$ ) in an aqueous a solution of $2 \mathrm{mM} \mathrm{AMP}_{\mathrm{T}}$ and $0.1 \mathrm{M} \mathrm{HBF}_{4}$.

To confirm the grafting of an aminophenyl (AMP) film, CVs were obtained at a modified GC electrode in $0.1 \mathrm{M} \mathrm{TBABF}_{4}-\mathrm{ACN}$. A broad irreversible oxidation peak observed at $\sim 1.2 \mathrm{~V}$ (Figure S4) confirms the presence of an aliphatic amine group. ${ }^{[17]}$

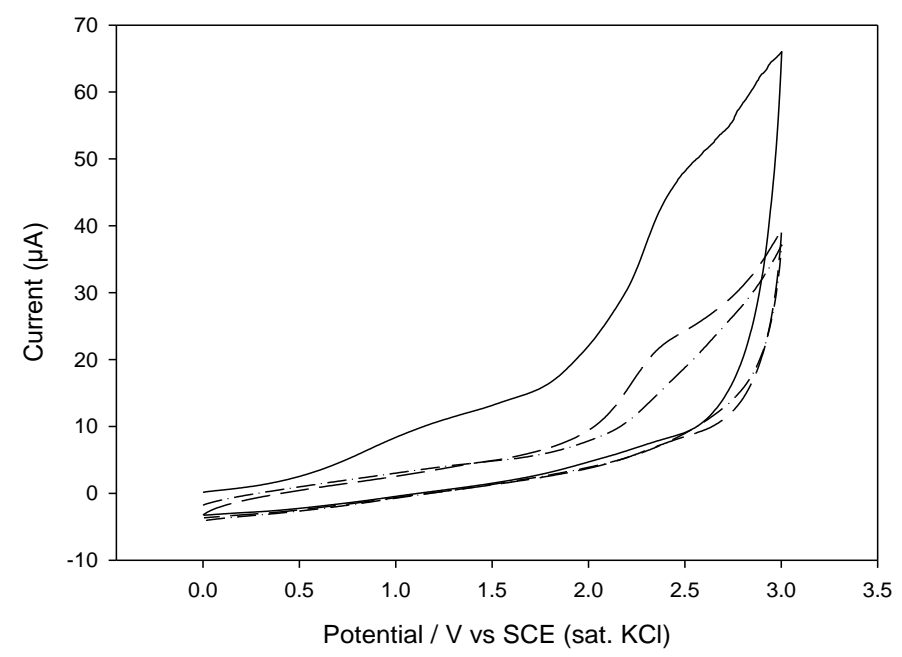

Figure S4. Repeat CVs (scan rate $=100 \mathrm{mV} \mathrm{s}^{-1}$ ) of an AMP-grafted electrode in $0.1 \mathrm{M} \mathrm{TBABF}_{4}-\mathrm{ACN}_{\text {. }}$

Modified PPF surfaces were examined by tapping-mode AFM. Figure S5 shows topographical images of bare PPF, and PPF modifed with an AMP film, prepared as described in Figure S3 caption. Although there is little apparent difference in morphology of the two samples, the rms surface roughness increased from 0.28 to $0.47 \mathrm{~nm}$ after grafting.

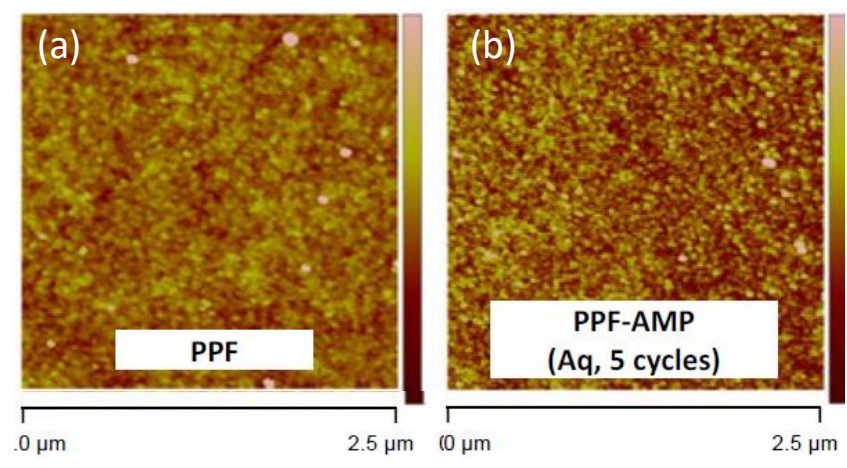

Figure S5. Tapping-mode AFM images of (a) bare PPF and (b) PPF with a grafted AMP film

\section{References}

[1] M. N. Hansen, E. Farjami, M. Kristiansen, L. Clima, S. U. Pedersen, K. Daasbjerg, E. E. Ferapontova, K. V. Gothelf, J. Org. Chem., 75, 2474-2481.

[2] P. A. Brooksby, A. J. Downard, Langmuir 2004, 20, 5038-5045. 
[3] D. C. Duffy, J. C. McDonald, O. J. A. Schueller, G. M. Whitesides, Anal. Chem. 1998, 70, 4974-4984.

[4] a) T. Breton, D. Belanger, Langmuir 2008, 24, 8711-8718; b) J. Lyskawa, D. Belanger, Chem. Mater. 2006, 18, 47554763.

[5] A. J. Downard, E. S. Q. Tan, S. S. C. Yu, New J. Chem. 2006, 30, 1283-1288.

[1] M. Geissler, Y. Xia, Adv. Mater. 2004, 16, 1249-1269.

[2] A. J. Downard, A. J. Gross, B. M. Simons, in Aryl Diazonium Salts: New Coupling Agents in Polymer and Surface Science (Ed.: M. M. Chehimi), Wiley-VCH, Weinheim, 2012, pp. 53-70.

[3] aM. Delamar, R. Hitmi, J. Pinson, J. M. Saveant, J. Am. Chem. Soc. 1992, 114, 5883-5884; bP. Allongue, M. Delamar, B. Desbat, O. Fagebaume, R. Hitmi, J. Pinson, J.-M. Saveant, J. Am. Chem. Soc. 1997, 119, $201-207$.

[4] aD. Belanger, J. Pinson, Chem. Soc. Rev. 2011, 40, 3995-4048; bJ. Pinson, F. Podvorica, Chem. Soc. Rev. 2005, 34, 429-439.

[5] B. P. Corgier, S. Bellon, M. Anger-Leroy, L. J. Blum, C. A. Marquette, Langmuir 2009, 25, 9619-9623.

[6] aD. J. Garrett, J. Lehr, G. M. Miskelly, A. J. Downard, J. Am. Chem. Soc. 2007, 129, 15456-15457; bJ. Lehr, D. J. Garrett, M. G. Paulik, B. S. Flavel, P. A. Brooksby, B. E. Williamson, A. J. Downard, Anal. Chem. 2010, 82, 70277034.

[7] aA. Adenier, E. Cabet-Deliry, A. Chausse, S. Griveau, F. Mercier, J. Pinson, C. Vautrin-U1, Chem. Mater. 2005, 17, 491-501; bI. Gallardo, J. Pinson, N. Vila, J. Phys. Chem. B 2006, 110, 19521-19529.

[8] aC. Cougnon, F. Gohier, D. Belanger, J. Mauzeroll, Angew. Chem. Int. Ed. 2009, 48, 4006-4008; bM. Kongsfelt, J. Vinther, K. Malmos, M. Ceccato, K. Torbensen, C. S. Knudsen, K. V. Gothelf, S. U. Pedersen, K. Daasbjerg, J. Am. Chem. Soc. 2011, 133, 3788-3791.

[9] J. L. Hudson, H. Jian, A. D. Leonard, J. J. Stephenson, J. M. Tour, Chem. Mater. 2006, 18, 2766-2770.

[10] P. J. A. Kenis, R. F. Ismagilov, G. M. Whitesides, Science 1999, 285, 83-85.

[11] P. J. A. Kenis, R. F. Ismagilov, S. Takayama, G. M. Whitesides, S. L. Li, H. S. White, Acc. Chem. Res. 2000, 33, 841847.

[12] aP. A. Brooksby, A. J. Downard, Langmuir 2004, 20, 5038-5045; bS. Ranganathan, R. L. McCreery, Anal. Chem. 2001, 73, 893-900.

[13] D. C. Duffy, J. C. McDonald, O. J. A. Schueller, G. M. Whitesides, Anal. Chem. 1998, 70, 4974-4984.

[14] F. Barriere, A. J. Downard, J. Solid State Electrochem. 2007, 12, 1231-1244.

[15] M. N. Hansen, E. Farjami, M. Kristiansen, L. Clima, S. U. Pedersen, K. Daasbjerg, E. E. Ferapontova, K. V. Gothelf, J. Org. Chem., 75, 2474-2481.

[16] aT. Breton, D. Belanger, Langmuir 2008, 24, 8711-8718; bJ. Lyskawa, D. Belanger, Chem. Mater. 2006, 18, 47554763.

[17] A. J. Downard, E. S. Q. Tan, S. S. C. Yu, New J. Chem. 2006, 30, 1283-1288. 